\title{
Yield and quality of warm-season grasses in central Texas
}

\author{
M. A. SANDERSON, P. VOIGT, AND R. M. JONES
}

Authors are research agronomist, USDA-ARS Pasture Systems and Watershed Management Research Laboratory, Curtin Road, University Park, Penn. 16802-3702. research geneticist, USDA-ARS Appalachian Soil and Water Conservation Laboratory, P.O. Box 400, Beaver, W. Virg. 25813-0400; and research scientist, Texas A\&M University Agricultural Research and Extension Center, Stephenville, Tex. 76401. At the time of the research, the senior author was associate professor, Texas A\&M University Agricultural Research and Extension Center, Stephenville, Tex.

\section{Abstract}

Warm-season perennial bunchgrasses frequently are used for hay and grazing in central Texas. We compared 6 alternative grasses with 2 more commonly grown species ['Ermelo' weeping lovegrass, (Eragrostis curvula (Schrad.) Nees var. curvula Nees) and 'Selection-75' kleingrass (Panicum coloratum L.] on 2 soils during 2 years. Grasses were transplanted into field plots at Stephenville and Temple, Tex. 1993 and harvested 3 times in 1994 and 1995. Weeping lovegrass and 'WW-B.Dahl' old world bluestem [Bothriochloa bladhii (Retz) S.T. Blake] were the highest yielding $(P<0.05)$ grasses and averaged 9,350 and 7,630 kg dry matter ha $\mathrm{ha}^{-1}$ in 1994 and 1995, respectively. 'Irene' tufted digitgrass (Digitaria eriantha Stued.) and kleingrass produced similar $(P>0.05)$ yields $\left(6,560\right.$ and $6,340 \mathrm{~kg}$ dry matter $\left.\mathrm{ha}^{-1}\right)$. Experimental line 409-704 buffelgrass [Cenchrus ciliaris L. syn. Pennisetum ciliare (L.) Link], 'Carostan' flaccidgrass (Pennisetum flaccidum Greisb.), 'Palar' Wilman lovegrass (Eragrostis superba Peyr.), and P.I. 269961 Oriental pennisetum (Pennisetum orientale Rich) yielded less than $3,000 \mathrm{~kg}$ dry matter $\mathrm{ha}^{-1}$ at Stephenville and were invaded by weeds. Tillers per plant generally explained most of the yield differences as plant density was held constant. Ermelo lovegrass and WW-B.Dahl old world bluestem produced 2 to 3 times more tillers plant ${ }^{-1}$ than other grasses. Concentrations of neutral detergent fiber were higher $(P<0.05)$ in digitgrass and the lovegrasses than in other grasses (39 vs $36 \%$ of dry matter). These data indicate that WW-B.Dahl old world bluestem and Irene tufted digitgrass should be useful in forage-livestock systems in central Texas.

Key Words: kleingrass, lovegrass, old world bluestem, digitgrass, flaccidgrass, buffelgrass

Animal production from rangeland-forage systems accounts for more than one-half of the annual $\$ 13$ billion of agricultural income in Texas (Bartek and Anderson 1993). Livestock operations within the 50 to $75 \mathrm{~cm}$ rainfall zone often combine rangeland with cropland, tame pas-

\footnotetext{
Manuscript accepted 13 Jun. 1998
}

\section{Resumen}

En la región central de Texas a menudo se utilizan zacates amacollados de crecimiento de verano para producir heno o ser pastoreados. Durante 2 años, en 2 tipos de suelo, comparamos 6 especies alternativas de zacate contra 2 especies comúnmente cultivadas, "Emerlo weeping lovegrass" [Eragrostis curvula (Shrad.) Nees var curvula Nees] y “Kleingrass" 'selección 75' (Panicum cloratum L.). En 1993, los zacates fueron transplantados a parcelas de campo en Stephenville y Temple, Tex. y cosechadas 3 veces durante 1994 y 1995. "Weeping Lovegrass" y 'WW-B. Dahl' "Old world bluestem" [Bothriochloa bladhii (Retz) S. T. Blake] fueron las especies más productivas $(\mathrm{P}<0.05)$ promediando 9,350 y 7,630 Kg materia seca ha $^{-1}$ en 1994 y 1995 respectivamente. 'Irene' "tufted digitgrass" (Digitaria eriantha Stued.) $Y$ "Kleingrass" tuvieron rendimientos similares $(P>0.05)$ $\left(6,560\right.$ y $6,430 \mathrm{Kg}$ materia seca $\left.\mathrm{ha}^{-1}\right)$. La línea experimental 409-704 de zacate "Buffel" [Cenchrus ciliaris $L$. syn Pennisetum ciliare (L.) Link.], 'Carostan' "Flaccidgrass" (Pennisetum flaccidum Griseb),'Palar' "Wilman lovegrass" (Eragrostis superba Peyr.) y P.I. 269961 “Oriental pennisetum" (Pennisetum orientale Rich.) Rindieron menos de 3,000 $\mathrm{Kg}$ materia seca $\mathrm{ha}^{-1}$ en Stephenville $\mathrm{y}$ fueron invadidos por maleza. Cuando la densidad de plantas fue constante, los hijuelos explicaron la mayoría de las diferencias en rendimiento. "Emerlo lovegrass" y "WW-B. Dahl "Old world bluestem" produjeron de 2 a 3 veces mas hijuelos por planta que las otras especies. Las concentraciones de fibra neutro detergente fueron mayores $(P<0.05)$ en "Kleingrass" y los "Lovegrasses" ( 69 a $78 \%$ de la materia seca) comparados con las otras especies (67\% de la materia seca). La fibra ácido detergente fue mayor $(P<0.05)$ en "Digitgrass" y los "Lovegrasses" que en las otras especies de zacate (39 vs $36 \%$ de la materia seca). Estos datos indican que "WW-B. Dahl "Old world bluestem" and 'Irene' "Tufted digitgrass deben ser útiles en los sistemas forraje-ganado de la región central de Texas.

tures, and hayland. These grazing lands and haylands frequently are planted to warm-season perennial grasses, which meet a significant forage need during the summer months in the southern Great Plains.

Kleingrass (Panicum coloratum L.) and weeping lovegrass (Eragrostis curvula (Schrad.) Nees var. curvula Nees) have been used frequently in the southern Great 
Plains. Kleingrass is adapted to a wide range of soils, recovers quickly from defoliation and drought, spreads rapidly, and is also used in wildlife plantings (Holt and Bashaw 1976, Holt et al. 1985). However, it may not survive some winters north of approximately $32.5^{\circ}$ latitude. Weeping lovegrass is adapted mainly to sandy soils in north Texas and in central to western Oklahoma (Voigt and Sharp 1994). It establishes easily, starts growth earlier, and may be grazed or cut earlier than other warm-season grasses in the spring. Nutritive value of weeping lovegrass, however, may be very low with improper grazing or harvest management (Mynhardt et al. 1994a).

To design effective forage systems, producers need information on productivity, quality, and persistence of species and varieties of warm-season grasses suitable for conserved forage. The objective of this study was to determine the potential of some alternative warm-season perennial grasses in the central Texas environment by evaluating them for yield, morphological traits, and nutritive value.

\section{Materials and Methods}

This research was conducted at the Texas Agricultural Experiment Station Blackland Research Center in Temple, Tex. and at the Texas A\&M University Agricultural Research and Extension Center in Stephenville, Tex. Temple is in the Blackland Prairie region of Texas, an area of gently rolling to level topography and fertile soils (Gould 1975). Stephenville (about $160 \mathrm{~km}$ north of Temple) is in the Cross Timbers region of Texas, an area of sandy, low fertility soils, and hilly terrain (Gould 1975). The soil at the Blackland Research Center is a Houston black clay (fine, montmorillonitic, thermic, Udic Pellusterts) and at Stephenville a Windthorst fine sandy loam (fine, mixed, thermic, Udic Paleustalfs).

Kleingrass and weeping lovegrass were compared with 6 alternative grasses (Table 1). Seedlings of each grass were transplanted from greenhouse pots to the field in April 1993

\begin{tabular}{||lll|}
\hline \hline \multicolumn{1}{||}{\begin{tabular}{l} 
Table 1. Warm-season perennial grasses evaluated at Stephenville and Temple, Tex. in $\mathbf{1 9 9 4}$ and \\
\hline \hline Scientific name
\end{tabular}} & Common name & Cultivar \\
\hline Digitaria eriantha Stued. & Tufted digitgrass & Irene \\
Cenchrus ciliaris L. & buffelgrass & $409-704$ \\
Eragrostis superba Peyr. & Wilman lovegrass & Palar \\
Pennisetum orientale Rich & Oriental pennisetum & PI 269961 \\
Bothriochloa bladhii (Retz S.T. Blake) & old world bluestem & WW-B.Dahl \\
Pennisetum flaccidum Greisb. & flaccidgrass & Carostan \\
Panicum coloratum L. & kleingrass & Selection-75 \\
Eragrostis curvula (Schrad.) Nees var. curvula Nees & weeping lovegrass & Ermelo \\
\hline
\end{tabular}

when the plants were 3-months old. Plots at Temple consisted of 4 rows (0.3 m between rows) $3.66 \mathrm{~m}$ long. Plots at Stephenville were 5 rows $(0.3$ $\mathrm{m}$ between rows) wide and $3.66 \mathrm{~m}$ long. Within-row plant spacing at each location was $0.3 \mathrm{~m}$. The experimental design at each location was a randomized complete block with 4 replicates. The plants were watered at transplanting and as necessary during the summer of 1993 to ensure establishment.

In 1994, plots at both locations were burned in March and $67 \mathrm{~kg} \mathrm{~N} \mathrm{ha}^{-1}$ and $78 \mathrm{~kg} \mathrm{P}_{2} \mathrm{O}_{5}$ were applied at Stephenville and $78 \mathrm{~kg} \mathrm{~N}$ was applied at Temple. In 1995, plots were clipped in March and $78 \mathrm{~kg} \mathrm{~N}^{-1}$ was applied at each location. Plots were not burned in 1995 because of insufficient fuel. Plots were harvested on 19 May, 28 June, and 29 August 1994 and 22 May, 10 July, and 25 September 1995 at Stephenville. Exceptions were WWB. Dahl old world bluestem, which was harvested twice each year (10 June and 29 August 1994; 20 June and 25 September 1995) and weeping lovegrass, which was harvested on 4 May, 20 June, and 25 September. At Temple, plots were harvested on 23 May, 7 July, and 7 October 1994, and 18 May, 3 July, and 28 September 1995. At each harvest, 4 plants per plot were clipped to a $7.6-\mathrm{cm}$ stubble by hand to determine tiller number per plant and individual tiller weight. Initial tiller counts were made in March 1994 at each location. To determine forage yield, the center 2 (Temple) or 3 (Stephenville) 3.66-m rows were clipped with a sickle-bar harvester to leave a $7.6 \mathrm{~cm}$ stubble. Fresh weight was recorded and a 450 g sample of harvested forage was placed in a cloth bag and dried at $55^{\circ}$ C for 48 hours to determine dry matter (DM) percentage.

Dried samples were ground sequentially through a $2 \mathrm{~mm}$ screen in a shear mill and through a $1 \mathrm{~mm}$ screen of an impact mill. Near-infrared reflectance spectroscopy (NIRS; Model 6250, Perstorp Analytical, Silver Spring, Md) was used to analyze samples for crude protein $(\mathrm{CP})$, neutral detergent fiber (NDF), acid detergent fiber (ADF), and acid detergent lignin (ADL). Samples for calibration were selected based on spectral characteristics via the programs CENTER and SELECT (Infrasoft International, Port Matilda, Penn.; Shenk and Westerhaus 1991).

Calibration (100 samples) and validation (19) samples were analyzed in duplicate for CP (Kjeldahl N x 6.25; Bremner 1965), NDF, ADF, and ADL (Van Soest and Robertson 1980). Sodium sulfite and decalin were omitted from NDF and ADF analyses; amylase (heat-stable $\alpha$-amylase; Sigma A3306, Sigma, St. Louis, Mo) was added during NDF analysis. A modified partial least squares procedure (Infrasoft International, Port Matilda, Penn.) was used to develop calibration equations. Calibration and validation statistics are in Table 2. Values for NDF, ADF, ADL, and CP were weighted by the dry weight from individual harvests and summed into annual values (Cherney and Volenec 1992).

The experiment was analyzed as a randomized complete block design with 4 replicates as blocks. A combined ANOVA indicated significant year by location by entry, year by 


\begin{tabular}{|c|c|c|c|c|c|c|c|c|}
\hline \multirow[b]{2}{*}{ Item } & \multicolumn{4}{|c|}{ Calibration } & \multirow[b]{2}{*}{$1-\mathrm{VR}$} & \multicolumn{3}{|c|}{ Validation } \\
\hline & $\mathrm{N}$ & Mean & SEC & SECV & & $\mathrm{N}$ & $\operatorname{SEP}(\mathrm{C})$ & $r^{2}$ \\
\hline & \multicolumn{5}{|c|}{ - - - - $\left(\mathrm{g} \mathrm{kg}^{-1}\right)-\ldots$} & \multicolumn{3}{|c|}{$\left(\mathrm{g} \mathrm{kg}^{-1}\right)$} \\
\hline Neutral detergent fiber & 97 & 69.4 & 0.94 & 1.10 & 0.96 & 19 & 1.17 & 0.97 \\
\hline Acid detergent fiber & 100 & 37.4 & 0.80 & 0.95 & 0.90 & 19 & 0.80 & 0.91 \\
\hline Acid detergent lignin & 98 & 3.97 & 0.25 & 0.32 & 0.84 & 19 & 0.36 & 0.82 \\
\hline Crude protein & 94 & 5.83 & 0.42 & 0.48 & 0.96 & 19 & 0.45 & 0.97 \\
\hline
\end{tabular}

entry, and location by entry interactions for DM yield and nutritive value, thus separate analyses were conducted for each location within each year. Tiller number and weight data were analyzed for individual harvests within each location and year, and plotted with a least significant difference (LSD, $\mathrm{P}<0.05$ ) value to show trends and patterns in tiller dynamics.

\section{Results and Discussion}

\section{Forage Dry Matter Yields}

WW-B.Dahl old world bluestem and Ermelo weeping lovegrass produced more forage dry matter than other species in 1994 and 1995 at both Stephenville and Temple (Fig. 1, 2). WW.B-Dahl old world bluestem matured about 1 month later in spring (June vs. May) relative to other old world bluestems such as 'WW-Spar' and 'WW-Ironmaster' at Stephenville (Sanderson et al. 1992.) and was later maturing than other grasses in the current experiment. WW-B.Dahl was originally collected in India, selected in Oklahoma, and released in 1994 (Dewald et al., 1995). WW-B.Dahl has been evaluated in Oklahoma, New Mexico, and west Texas; these are the first reported data on its performance in central Texas. Its performance in this experiment indicates that it is adapted to diverse soils and climate conditions.

Tufted digitgrass produced as much forage as kleingrass except at Temple in 1994 when digitgrass yielded less. These data indicate that tufted digitgrass does as well as kleingrass on both sandy and clay soils. Further evaluations are needed to determine its winter survival at locations farther north in the southern plains. If adapted, digitgrass would be an alternative in areas where kleingrass has marginal winter survival. Much of the information available on digitgrass for the southern U.S. pertains to stoloniferous types such as 'Pangola' in the southeastern U.S., particularly Florida (Ocumpaugh and Sollenberger 1994).

The tufted types of digitgrass may be more adapted to lower rainfall areas than the stoloniferous types (Theunissen 1995) and some may be more winterhardy (Oakes and Langford 1967).

F laccidgrass, Oriental pennisetum, and buffelgrass were the lowest yielding species at Stephenville in both years. These species grew slowly in the spring of 1994 and 1995 at Stephenville, and by late summer they had little regrowth. These plots also became infested with crabgrass [Digitaria ciliaris (Retz) Koel] and Texas panicum (Panicum texanum L.).

Buffelgrass generally does not persist north of San Antonio, Texas (approximately $29.5^{\circ} \mathrm{N}$ latitude; M.A. Hussey, personal communication, 1996) and it did not survive more than 3 years in previous trials at Stephenville (Sanderson et al. 1991). We included 409-704 buffelgrass in this experiment because it had been selected for improved winter survival (Hussey and Bashaw 1996). Hussey and Bashaw (1996) evaluated 409-704 buffelgrass and 'Cowboy' $P$. orientale at Stephenville during 1987 to 1988 and reported winter survival scores of 83 and $100 \%$ respectively, which were higher than for commercially released cultivars of buffelgrass. Plots were visually rated for winter survival in spring 1996 at Stephenville and no significant plant loss was observed. Thus, even though winterhardiness in 409-704 buffelgrass has been improved, its low yield in field production would not be acceptable in central Texas or similar environments.

Yields at Temple in 1995 were sig-

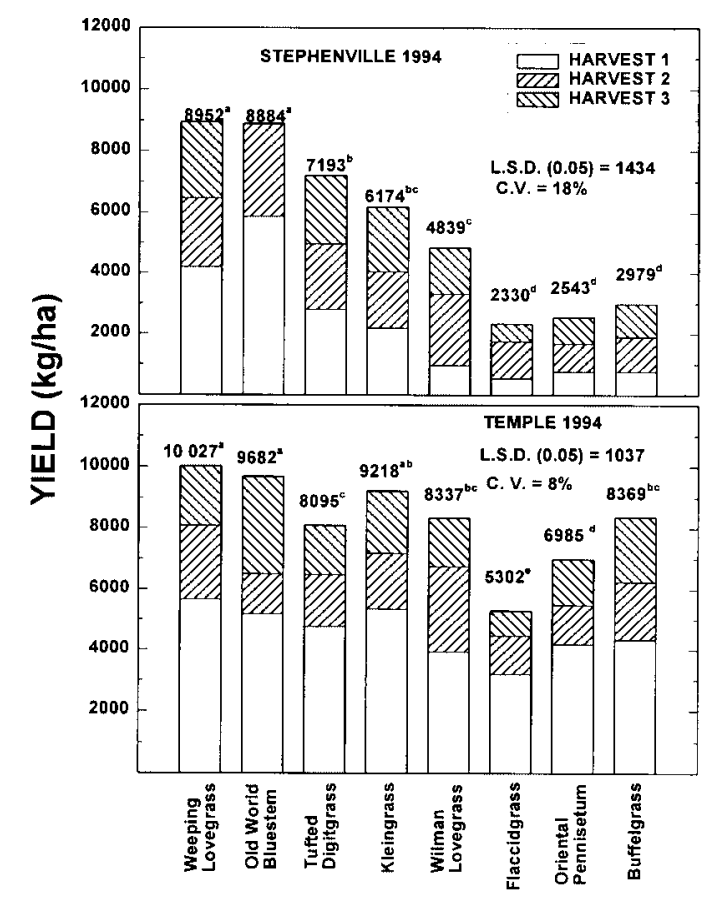

Fig 1. Forage dry matter yields of 8 warm-season perennial grasses at Stephenville and Temple, Tex. in 1994. Means with different superscripts differ at $\mathbf{P}<0.05$. L.S.D. = least significant difference. $\mathrm{CV}=$ coefficient of variation. 


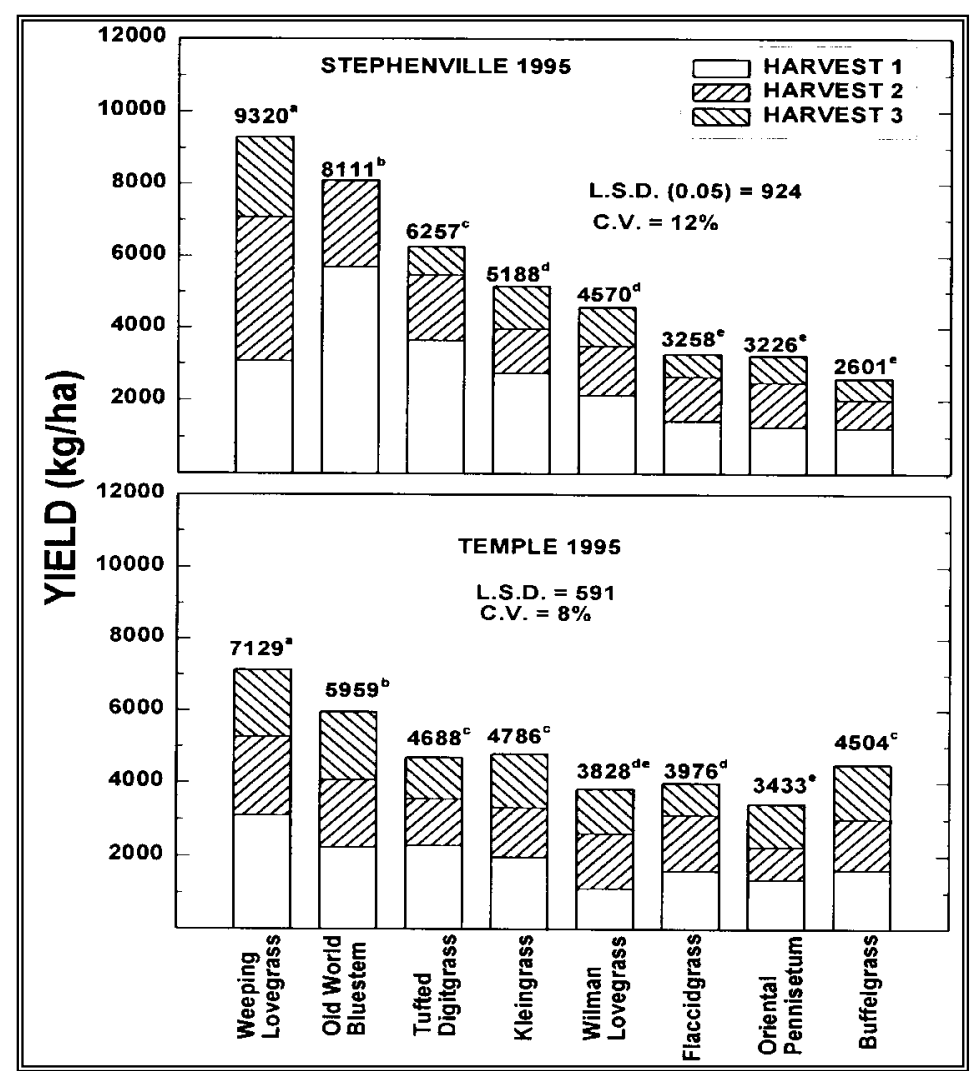

Fig. 2. Forage dry matter yields of 8 warm-season perennial grasses at Stephenville and Temple, Texas in 1995. Means with different superscripts differ at $\mathbf{P}<0.05$. L.S.D. = least significant difference. $\mathrm{CV}=$ coefficient of variation

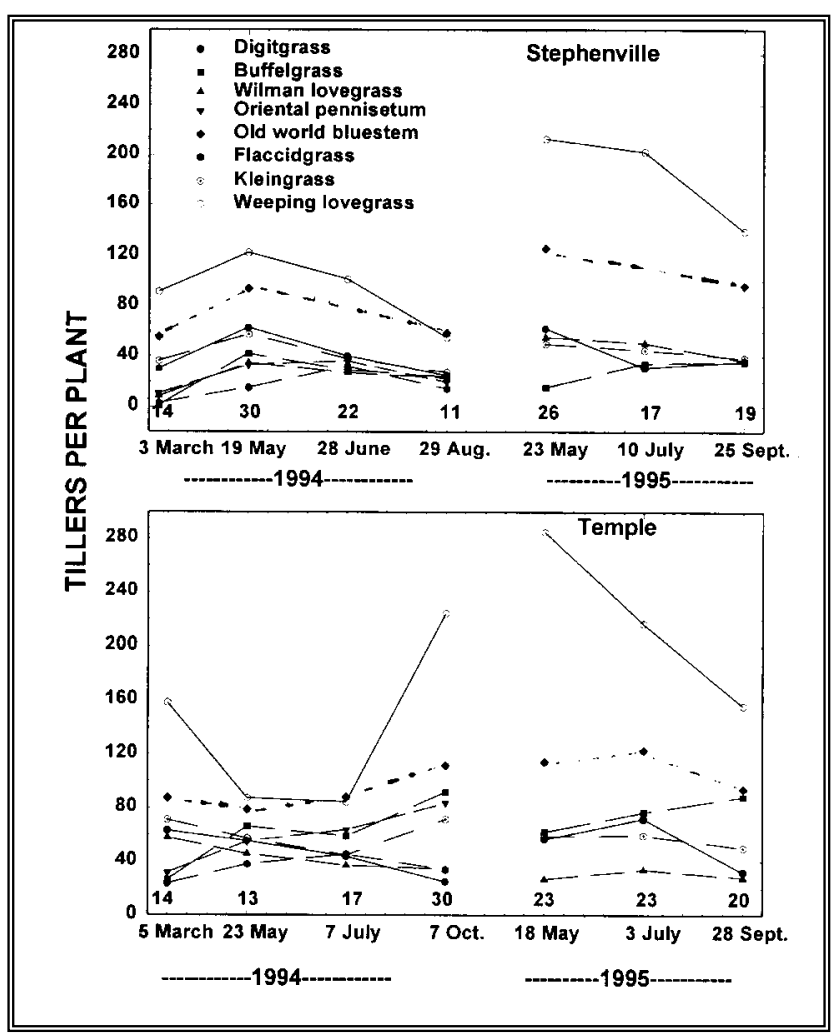

Fig. 3. Tiller numbers (per plant) of 8 warm-season grasses at Stephenville and Temple, Texas during 2 years. Data are averages of 4 replicates and 4 plants per replicate. Numbers along the bottom axis are least significant difference (L.S.D.) values at $\mathbf{P}<0.05$. nificantly lower than in 1994 with the largest reductions occurring at the May harvest (Fig. 1 and 2). Weeping lovegrass and Wilman lovegrass yields decreased by 29 and $25 \%$, respectively, between 1994 and 1995 . Yields of other species were reduced by 39 to $54 \%$ from 1994 to 1995 . Rainfall in January and February of 1995 at Temple was less than one-half of normal (4.5 vs $12.2 \mathrm{~cm}$ for the 30 year average); however, rainfall during March through May was normal or above normal. Thus, early season growth in 1995 probably was not limited by rainfall. Temperatures during March to June were 1 to $2^{\circ} \mathrm{C}$ below normal, which may also have reduced yields the following year. Rainfall at Temple during August through October of 1995 was $13.6 \mathrm{~cm}$ below the normal of $22.2 \mathrm{~cm}$, which limited regrowth during late summer and delayed the final harvest until October. Rainfall at Stephenville was above normal in both years $(96$ and $90 \mathrm{~cm}$ in 1994 and 1995, respectively, compared with 30 year average of $74 \mathrm{~cm}$ ).

\section{Tiller Dynamics}

Tillers per plant generally explained most of the yield differences among species as plant density was held constant. In general, the lowest yielding species had the fewest tillers per plant. Ermelo weeping lovegrass and WWB.Dahl old world bluestem had the greatest number of tillers per plant at most harvests at Stephenville and Temple in 1994 and 1995 (Fig. 3). Tiller numbers at Stephenville were highest at the May harvest each year (except for flaccidgrass in 1994 and buffelgrass in 1995) and declined at subsequent harvests. In 1995, it was difficult to determine the boundaries of individual plants of flaccidgrass and Oriental pennisetum at both locations because of their rhizomatous growth habit. Therefore, tiller counts were not reliable and are not presented.

Tiller weights varied inversely with tiller numbers $(r=-0.27, P<0.05, n=$ 96). Weeping lovegrass tillers were lighter than many other grasses at some harvests (Fig. 4), but its ability to produce a large number of tillers per plant (Fig. 3) contributed to its higher yields. Mynhardt et al. (1994b) reported that the ability of weeping lovegrass to produce large numbers of lateral tillers contributed to its competitiveness in South African pastures. At Stephenville, tillers of WW-B.Dahl old world bluestem were among the heaviest, which along with a high number of tillers per plant contributed to its higher yields compared with other grasses. At Temple, tiller weights of WW-B.Dahl were intermediate to those of other grasses. The increase in Wilman lovegrass tiller weight in July and September of 1994 at Stephenville was associated with a decrease in tiller numbers at these dates. Tiller weights of all grasses at Temple decreased as the season progressed in 1994 with the exception of tufted digitgrass. Wilman lovegrass, kleingrass, or tufted digitgrass had the heaviest tillers at each harvest in both years. But, these grasses were also among those with the fewest tillers per plant. 


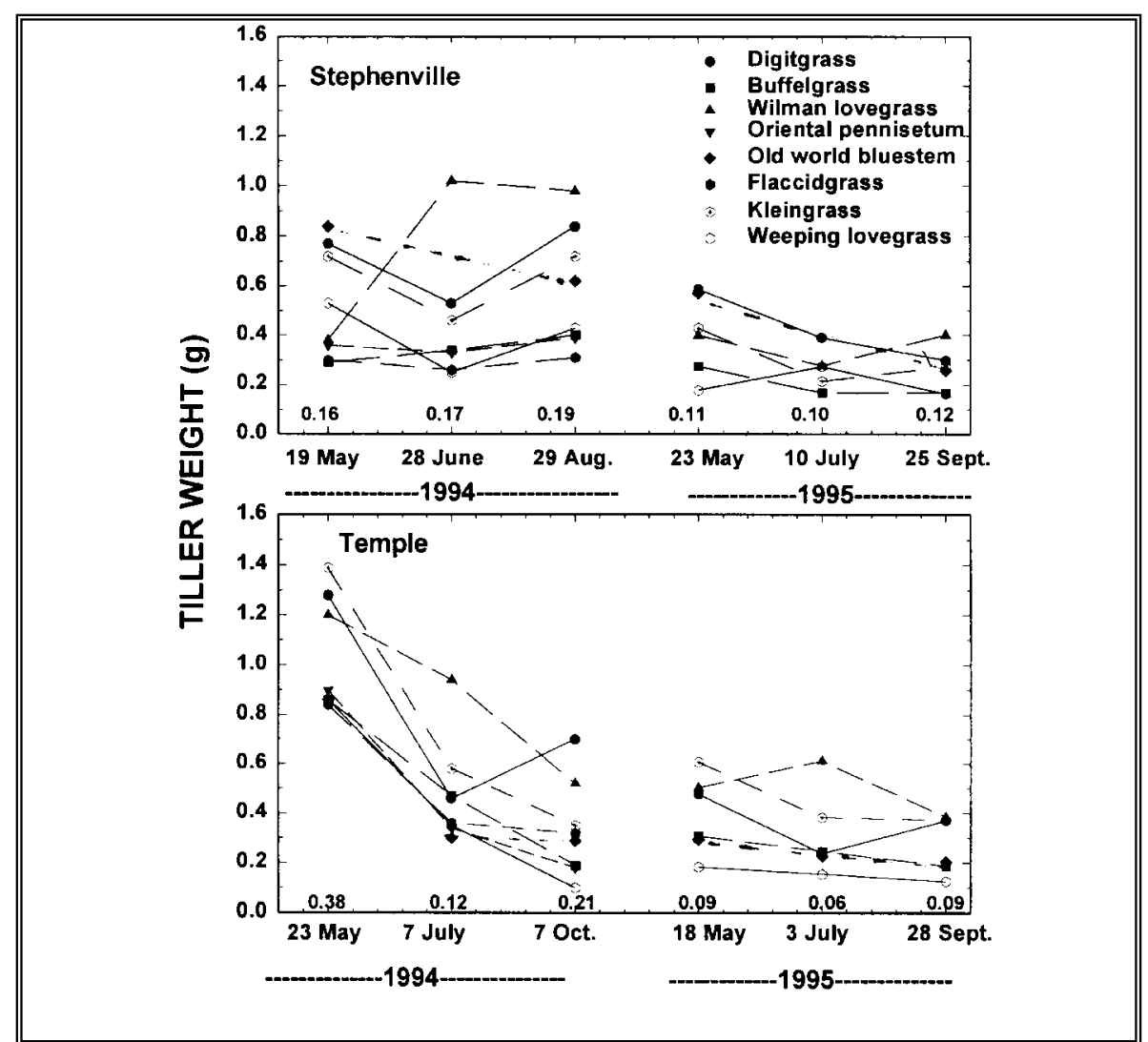

Fig. 4. Individual tiller weight of 8 warm-season grasses at Stephenville and Temple, Texas during 2 years. Data are averages of 4 replicates and 4 plants per replicate. Numbers along the bottom axis are least significant difference (L.S.D.) values at $P<0.05$.

In spaced planted swards of grasses, tiller number generally influences forage yield more than does tiller weight until a dense, closed sward forms (Zarrough et al. 1983a, 1983b, Montero and Jones 1992). In our study, plants were spaced relatively wide, and a dense, closed sward did not form as may happen in temperate, humid climates. We established these plots by transplants to ensure uniform stands of all entries at each location. Denser swards may be formed under farm and ranch conditions where the grasses would likely be planted with a drill or broadcast seeded (Welch and Hafercamp 1981). A denser canopy may have limited weed invasion into plots of some of the lower yielding species.

\section{Nutritive Value}

Because of significant year by location by species interactions, nutritive value data are presented by individual locations and years. Nutritive value of these species was typical for warmin CP (Van Soest 1994). The love- grasses had the highest NDF concentrations at both locations followed by kleingrass (Table 3). Tufted digitgrass and the lovegrasses had the highest ADF concentrations. Rankings for ADL concentrations were similar to those for NDF.

WW.B-Dahl had lower detergent fiber concentrations than weeping lovegrass (Table 3 ) indicating that animal intake of the old world bluestem may be greater than lovegrass. On the other hand, $\mathrm{CP}$ concentrations in WWB.Dahl were lower than weeping lovegrass at Stephenville, but similar or higher at Temple. Both forages would likely need to be supplemented with protein depending on the class of stock to be fed.

Weighted CP concentrations of all grasses were low, about 4 to $8 \%$. The highest $\mathrm{CP}$ concentrations occurred in primary growth (8 to $12 \%$, data not shown), whereas regrowth from later harvests was very low in CP $5 \%$ or less, data not shown). McMurphy et al. (1975) also noted similar seasonal trends for weeping lovegrass in Oklahoma where CP was $10 \%$ in first (June) harvest forage and 5\% in forage harvested in August. Huston et al. (1981) reported very low CP (2 to 7\%) in mature forage of several warm-sea-

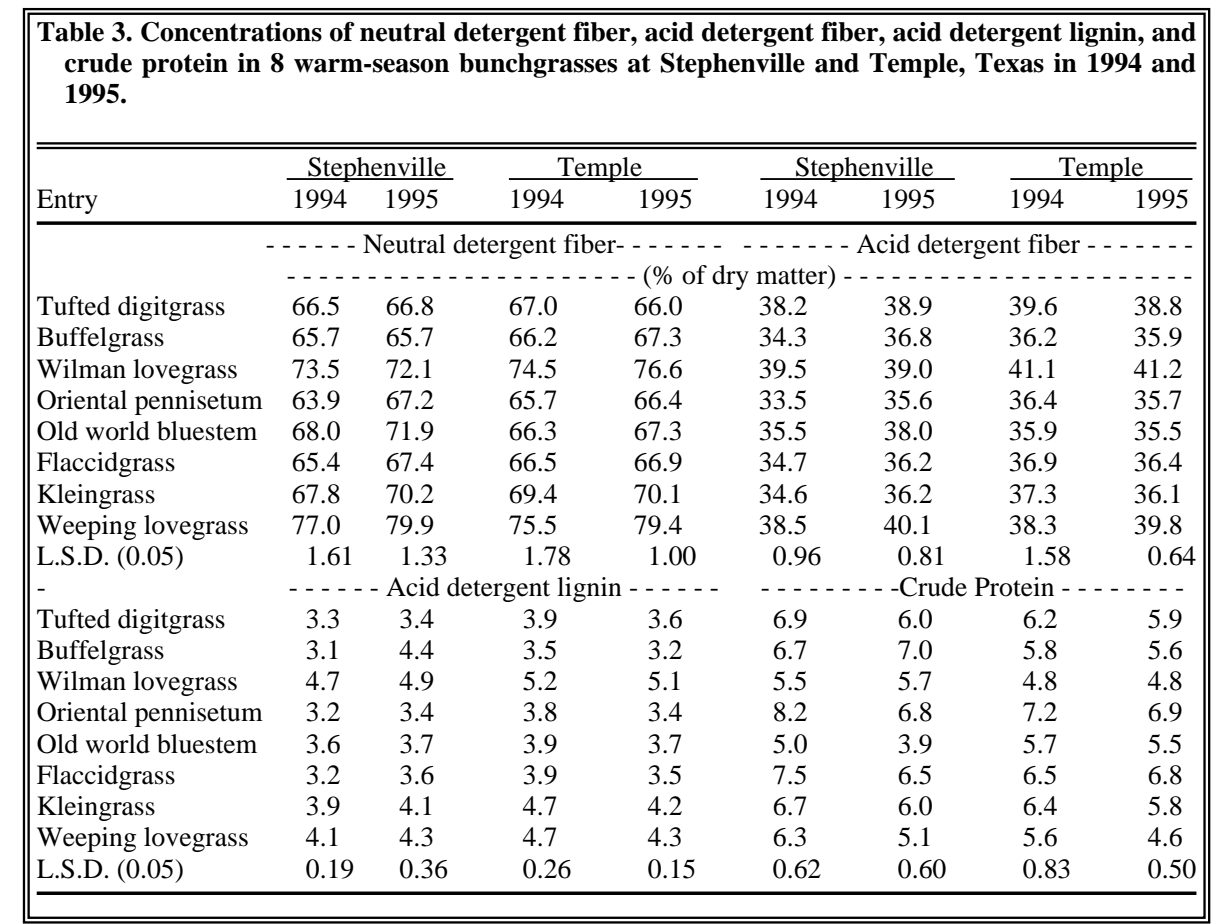


son range grasses in the Edwards Plateau of Texas. Heckathorn and Delucia (1996) demonstrated that warm-season prairie grasses translocated shoot nitrogen to below ground organs during drought. Water-deficit stress can develop quickly on the sandy Windthorst soil at Stephenville, thus translocation of nitrogen may have occurred and lowered nitrogen concentrations in the grasses. The low $\mathrm{CP}$ concentrations in our study may also have resulted from relatively low amounts $\left(78 \mathrm{~kg} \mathrm{ha}^{-1}\right)$ of nitrogen fertilizer used.

\section{Conclusions}

WW B-Dahl old world bluestem and Irene tufted digitgrass are promising alternative forage grasses for livestock-forage systems under limited nitrogen fertilizer inputs in Texas. Both grasses performed as well as weeping lovegrass or kleingrass and the nutritive value of both was superior to lovegrass. WW-B.Dahl matured about 1 month later than other old world bluestems. Oriental pennisetum, flaccidgrass, and 409-704 buffelgrass (selected for improved winter survival) persisted for 3 winters at Stephenville; however, their poor forage production indicates that there may be other factors limiting their growth in this environment.

\section{Literature Cited}

Bartek, B.L. and C.G. Anderson. 1993. Estimated value of agricultural production and related items 1989-1992. Texas Agr. Ext. Serv. College Station, Tex.

Bremner, J.M. 1965. Inorganic forms of nitrogen. p. 1179-1237. In: C.A. Black et al. (ed.) Methods of soil analysis. Part 2. Agron. Monogr. 9. ASA and SSSA, Madison, Wisc.

Cherney, J.H. and J.J. Volenec. 1992. Forage evaluation as influenced by environmental replication: A review. Crop Sci. 32:841-846.

Dewald, C.L., P.L. Sims, and W.A. Berg. 1995. Registration of 'WW-B.Dahl' old world bluestem. Crop Sci. 35:937.

Gould, F.W. 1975. Texas plants: A checklist and ecological summary. Texas Agr. Exp. Sta. Bull. MP-785. College Station, Tex.
Heckathorn, S.A. and E.H. Delucia. 1996. Retranslocation of shoot nitrogen to rhizomes and roots in prairie grasses may limit loss of $\mathrm{N}$ to grazing and fire during drought. Func. Ecol. 10:396-400.

Holt, E.C. and E.C. Bashaw. 1976. Developing improved grasses and legumes. p. 2-25. In: E.C. Holt and R.D. Lewis (ed.) Grasses and legumes in Texasdevelopment, production, and utilization. Texas Agr. Exp. Sta. Res. Monograph 6C. College Station, Tex.

Holt, E.C., J.R. Cain, and R.J. Hendler. 1985. Evaluation and management of grasses for dual livestock and game bird use. J. Range Manage. 38:342-346.

Hussey, M.A. and E.C. Bashaw. 1996. Performance of buffelgrass germplasm with improved winter survival. Agron. J. 88:944-946.

Huston, J.E., B.S. Rector, L.B. Merrill, and B.S. Engdahl. 1981. Nutritional value of range plants in the Edwards Plateau region of Texas. Texas Agr. Exp. Sta. Bull. B-1357. College Station, Tex.

McMurphy, W.E., C.E. Denman, and B.B. Tucker. 1975. Fertilization of native grass and weeping lovegrass. Agron. J. 67:233-236.

Montero, C.M. and T.A. Jones. 1992. Establishment of 'Hycrest' crested and T21076 Thickspike wheatgrasses in three environments. Crop Sci. 32:1016-1020.

Mynhardt, J.E., M.W. van Rooyen, and G.K. Theron. 1994a. Competitive ability of two grass species: Anthephora pubescens and Eragrostis curvula. 1. Yield and biomass allocation. S. Afr. J. Bot. 60:261-268.

Mynhardt, J.E., M.W. van Rooyen, and G.K. Theron. 1994b. Competitive ability of two grass species: Anthephora pubescens and Eragrostis curvula. 2. Growth analysis. S. Afr. J. Bot. 60:262-273.

Oakes, A.J. and W.R. Langford. 1967. Cold tolerance in Digitaria. Agron. J. 59:387-388.

Ocumpaugh, W.R. and L.E. Sollenberger. 1994. Other grasses for the humid south. p. 441-449. In: Barnes, R.F, D.A. Miller, and C.J. Nelson (ed.) Forages: an introduction to grassland agriculture. Vol. 1. Iowa State Univ. Press, Ames, Iowa.

Sanderson, M.A., R.M. Jones, and J.S. Newman. 1991. Productivity of 10 warmseason perennial grasses over several years in Central Texas. Texas Agr. Exp. Sta. Bull. B-1695. College Station, Tex.

Sanderson, M.A., R.M. Jones, and J. Ward. 1992. Yields of warm-season grasses at Stephenville. p. 18-20. In: Forage Research in Texas, 1992. Texas Agr. Exp. Sta. Consolidated progress report PR-5019, College Station, Tex.
Shenk, J.S. and M.O. Westerhaus. 1991. Population structuring of near infrared spectra and modified partial least squares regression. Crop Sci. 31:1548-1555.

Theunissen, J.D. 1995. Biomass production of different ecotypes of three grass species of the semi-arid grasslands of Africa. J. Arid Environ. 29:439-445.

Van Soest, P.J. 1994. Nutritional ecology of the ruminant. Cornell Univ. Press, Ithaca, N.Y.

Van Soest, P.J. and J.B. Robertson. 1980. Systems of analysis for evaluating fibrous feeds. p. 49-60. In: W.J. Pigden et al. (ed.) Proc. Intl Workshop on Standardization Anal. Meth. Feeds, Ottawa, Canada. 12-14 Mar. 1979. IRDC-134e. Unipub, New York.

Voigt, P.W. and W.C. Sharp. 1994. Grasses of the plains and southwest. p. 395-408. In: Barnes, R.F, D.A. Miller, and C.J. Nelson (ed.) Forages: an introduction to grassland agriculture. Vol. 1. Iowa State Univ. Press, Ames, Iowa.

Welch, T.G. and M.R. Hafercamp. 1981. Seedling rangeland. Texas. Agr. Ext. Serv. Bull. B-1379. College Station, Tex.

Zarrough, K.M., C.J. Nelson, and J.H. Coutts. 1983a. Relationship between tillering and forage yield of tall fescue: I. Yield. Crop Sci. 23:333-337.

Zarrough, K.M., C.J. Nelson, and J.H. Coutts. 1983b. Relationship between tillering and forage yield of tall fescue: II. Pattern of tillering. Crop Sci. 23:338-342. 